Crarke, P. H. (1953). J. gen. Microbiol. 9, 350-352.

\title{
Growth of Streptococci in a Glucose Phenolphthalein Broth
}

\author{
By PATRICIA H. CLARKE \\ National Collection of Type Cultures, Colindale Avenue, London, N.W. 9
}

SUMMARY: A liquid medium buffered at pH $9 \cdot 6$ is described which is modified from that of Shattock \& Hirsch (1947) by the addition of phenolphthalein and in the method of preparation. Its use in distinguishing streptococcal species was investigated.

Shattock \& Hirsch (1947) described a liquid glycine-buffered medium for

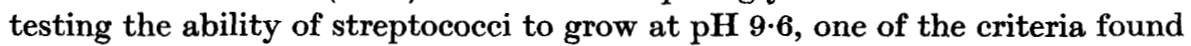
useful by Sherman \& Stark (1934) and Shattock \& Mattick (1943-44) for distinguishing Streptococcus faecalis from Strep. lactis. This medium was used by Shattock (1949) and by Sharpe \& Shattock (1952) in studies on group D streptococci and Strep. lactis. It was thought that if a suitable indicator could be added to the medium it might be possible to dispense with the electrometric measurement of $\mathrm{pH}$ value, and as streptococci readily produce acid from glucose, growth would be accompanied by a change in colour of the indicator. Phenolphthalein with a pK of $9 \cdot 7$ was selected.

\section{PREPARATION OF MEDIUM}

The medium was prepared as described by Shattock \& Hirsch (1947) with the modifications discussed above. Only $100 \mathrm{ml}$. were prepared at a time, sufficient for testing about sixteen strains.

(1) Stock Lemco broth $\mathrm{pH} 7 \cdot 0+1 \% \mathrm{w} / \mathrm{v}$ glucose.

(2) Glycine buffer: glycine, 0.75 g.; $\mathrm{NaCl}, 0.585 \mathrm{~g}$., were dissolved in $100 \mathrm{ml}$. freshly boiled distilled water. To $60 \mathrm{ml}$. glycine $+\mathrm{NaCl}$ were added $40 \mathrm{ml}, 0 \cdot 1 \mathrm{~N}-\mathrm{NaOH}$ to make solution (2).

(3) Set of buffer solutions pH 9.5, 9.6, 9.7, 9.8, 9.9. Clark \& Lubs borate buffers were used as they were less likely to become contaminated. $20 \mathrm{ml}$. were prepared at each $\mathrm{pH}$ value, to which $0.1 \mathrm{ml} .0 .2 \%$ phenolphthalein was added. After mixing, the solutions were poured into bijou bottles (c. $5 \mathrm{ml}$.) and the caps screwed tightly to exclude air. They remained unchanged for at least 2 weeks.

To $90 \mathrm{ml}$. solution (1) were added $10 \mathrm{ml}$. solution (2) and $0.5 \mathrm{ml}$. phenolphthalein, and the reaction adjusted to $\mathrm{pH} 9.9$ with $\mathrm{N}-\mathrm{NaOH}$ by matching with the buffers in the bijou bottles, but any standard method for matching $\mathrm{pH}$ indicators may be used. No difficulty was experienced in matching the colours but the accuracy obtained was not greater than $\pm 0.25 \mathrm{pH}$ unit. The medium was kept overnight in a refrigerator and then passed through a Seitz filter. Occasionally precipitation continued after filtration, but this was ignored as it did not affect the results. The sterile medium was distributed into 
bijoux bottles leaving as little air space as possible. The bottles were incubated overnight to check sterility and on the next day inoculated from $24 \mathrm{hr}$. agar or serum agar slope cultures. The colour of the medium at this stage is a definite clear pink. Any bottles in which the pH value has fallen to $\mathrm{pH} \mathrm{9 \cdot 2}$ or less will appear a pale orange pink colour and can be discarded. This makes possible a check on each individual bottle before inoculation. Uninoculated bottles and known positive and negative organisms were included in each set of tests. Tests were carried out at $37^{\circ}$ and $30^{\circ}$. Controls were prepared of the buffered medium adjusted to $\mathrm{pH} 7 \cdot 0$ with bromthymol blue as indicator, and without indicator. Tubes of glucose peptone water as used for fermentation tests were incubated concurrently in a number of the tests.

Only a small number of strains has been tested; the group $\mathbf{D}$ and group $\mathbf{N}$ strains maintained in the N.C.T.C., strains of Strep. lactis kindly provided by Dr Shattock from her collection, and representative N.C.T.C. strains of the other serological groups of streptococci, and strains of Aerococcus viridans (Williams, Hirch \& Cowan, 1953).

\section{RESULTS}

The medium was simple to prepare and proved quite satisfactory in use. The reaction after filtration varied between $\mathrm{pH} 9 \cdot 5-9 \cdot 6$. Out of twelve batches of medium only an occasional bottle gave a $\mathrm{pH}$ value of $\mathbf{9 \cdot 2}$ or less, appearing orange-pink instead of a clear definite pink colour. Two Strep. lactis strains tested in media at about $\mathrm{pH} \mathrm{9.2}$ were able to grow whereas no growth occurred in the medium at $\mathrm{pH} 9 \cdot 5-9 \cdot 6$.

The results were clear-cut with the Strep. lactis and Strep. faecalis strains tested at $30^{\circ}$ and $37^{\circ}$. All the Strep. faecalis strains grew with acid production in $24 \mathrm{hr}$. and none of the Strep. lactis in 24 or $48 \mathrm{hr}$. in repeated tests (Table 1). In the medium at $\mathrm{pH} 7 \cdot \mathbf{0}$, with or without bromthymol blue and in glucose peptone water, both species grew and produced acid in $24 \mathrm{hr}$. None of the strains of Strep. bovis grew at $\mathrm{pH} 9 \cdot 6$. For Strep. durans this $\mathrm{pH}$ is obviously near the critical limits for growth. Shattock \& Hirsch (1947) found that nine out of eleven strains grew at pH 9.6. In repeated tests two of our six strains grew

Table 1. Ability of Streptococcus species to grow in a medium at $\mathrm{pH} \mathbf{9 \cdot 6}$ Results after incubation for $24 \mathrm{hr}$.

Serological group
Group D

Group $\mathbf{N}$

Groups A, B, C, E, G, M

$\quad$ Species
Strep. faecalis
Strep. liquefaciens
Strep. zymogenes
Strep. durans
Strep. bovis
Unclassified
Strep. lactis
Aerococcus viridans

Aerococcus viridans

\begin{tabular}{|c|c|}
\hline \multicolumn{2}{|c|}{ No. of strains } \\
\hline $\begin{array}{l}\text { Growing } \\
\text { at pH 9.6 }\end{array}$ & $\begin{array}{c}\text { Not growing } \\
\text { at pH 9.6 }\end{array}$ \\
\hline 14 & 0 \\
\hline 7 & 0 \\
\hline $\mathbf{3}$ & o \\
\hline 2 & 4 \\
\hline 0 & 6 \\
\hline $\mathbf{2}$ & $\mathbf{2}$ \\
\hline $\mathbf{0}$ & 14 \\
\hline $\mathbf{0}$ & 28 \\
\hline 10 & 0 \\
\hline
\end{tabular}




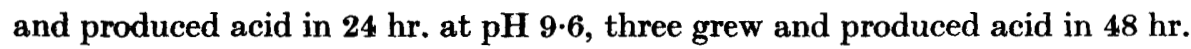
but not in $24 \mathrm{hr}$., and one strain failed to grow in 3 days. All ten Aerococcus viridans strains grew at $\mathbf{p H ~ 9 \cdot 6 .}$

These results agree with those obtained by Shattock \& Hirsch. The simplified method of preparation of this medium may contribute to the more general use of this test for growth at $\mathrm{pH} \mathrm{9.6.}$

\section{REFERENCES}

Sharpe, M. E. \& Shatrock, P. M. F. (1952). The serological typing of group D streptococci associated with outbreaks of neonatal diarrhoea. J. gen. Microbiol. 6, 150 .

ShatTock, P. M. F. (1949). The streptococci of Group D; the serological grouping of Streptococcus bovis and observations on serologically refractory group D strains. J. gen. Microbiol. 3, 80.

Shatrock, P. M. F. \& Hirsch, A. (1947). A liquid medium buffered at pH 9.6 for the differentiation of Streptococcus faecalis from Streptococcus lactis. J. Path. Bact. 59, 495.

Shatrock, P. M. F. \& Matrick, A. T. R. (1943-44). The serological grouping of Streptococcus lactis (Group N) and its relationship to Streptococcus faecalis. J. Hyg., Camb. 43, 173.

Sherman, J. M. \& Stark, P. (1934). The differentiation of Streptococcus lactis from Streptococcus faecalis. J. dairy Sci. 17, 325.

Williams, R. E. O., Hirch, A. \& Cowan, S. T. (1953). Aerococcus, a new bacterial genus. J. gen. Microbiol. 8, 475. 